\title{
Background and Literature Review of Global Value Chains
}

\author{
Sourish Dutta \\ $\mathrm{PhD}$ Student \\ Centre for Development Studies \\ Trivandrum, Kerala
}

\begin{abstract}
The phenomenon of global value chains (GVCs) indicates a division of labour type production structure in which tasks and business functions are distributed among several companies, globally, or regionally (Grossman and Rossi-Hansberg 2008). The critical features of GVCs are therefore the international dimension of the production process and the "contractualisation" of buyer and seller relationships, often across international borders (Antras 2016). As a result, these international production networks are highly complex regarding geography, technology, and the different types of firms involved (from large retailers and highly large-scale mechanised manufacturers to small home-based production). Sometimes it may be impossible even to identify all the countries that are involved or the extent of their involvement (Gereffi and FernandezStark 2016). However, the recent development of OECD-WTO's Trade-in Value Added (TiVA) data represents a fundamental step forward in understanding GVC trade. Grossman \& RossiHansberg $(2008,2012)$ rightly point out that the different tasks, rather than sectors, define the specialisation of countries in the value chains.
\end{abstract}

\section{Research Background}

\subsection{Motivation}

A couple of major developments in the global economy, such as the revolution in ICT, deepening of trade liberalisation (and continuing transportation cost reduction) as well as some recent political developments are expanding the reach of globalisation through a gradual fragmentation of production processes across countries. Nowadays most of the products are composed of different designs and 
components produced by many suppliers (firms) with their operations in various countries, creating the global production networks. In fact, the typical "Made in" labels on manufactured goods have become old symbols of the past era. These days, more and more products are "Made in the World" rather than "Made in the USA" or "Made in China" (Antràs 2016).

Indeed, the global production (as a system of creating values in geographically separated tasks or phases) is eventually forming a world wide web of economic values or value added that explains the transitional structure of international trade and development. It is truly a new wave of globalisation, and it is termed as the global value chains (GVCs), creating the nexus among firms, workers and consumers around the globe. In general, from a industrial organisation perspective, value chains describe the sequence of productive (value-added) activities that capital and labour (or firms and workers) perform to bring a good or service from its conception to end use and beyond (Porter 1985, Sturgeon 2001). "Value chain analysis" is intended as the science of identifying bottlenecks and opportunities between different stages of production and tasks. It includes activities such as designing, administrative services, manufacturing, assembling, marketing, distribution and customer services. In the context of globalisation, these tasks that constitute a value chain have been carried out in inter-firm and intra-firm networks on a global scale (Gereffi et al. 2001, 2005). These value chains can be regional if the scope of production takes place within the same geographic region. From an economic perspective, the phenomenon of global value chains (GVCs) identifies a production structure in which tasks and business functions are distributed among several companies, globally, or regionally (Grossman \& Rossi-Hansberg 2012). The key features of GVCs are therefore the international dimension of the production process and the "contractualisation" of buyer and seller relationships, often across international borders (Antràs 2016). As a result, these international production networks are highly complex regarding geography, technology, and the variety of types of firms involved (from large retailers and highly large-scale mechanised manufacturers to small home-based production). Sometimes it may be impossible even to identify all the countries that are involved or the extent of their involvement (Gereffi \& Fernandez-Stark 2016). However, increasing international disintegration of production processes has been large enough to be salient in aggregate statistics.

GVC is truly a breakdown in the vertically-integrated mode of production-the so-called "Fordist" production. A variety of terms have been used to refer to this phenomenon: the "slicing of the value chain", "fragmentation of the production process", "disintegration of production", "delocalization", "vertical specialization", "global production sharing", "unbundling", "offshoring", "outsourcing" and many more (Antràs 2016, Feenstra 1998). We may use these terms interchangeably. 
Grossman \& Rossi-Hansberg (2012) rightly point out that the different tasks, rather than sectors, define the specialisation of countries in the value chains. The emergence of this new scenario is asking how an economy's production processes, producers and employees are connecting to the world trade and capturing the gains out of it regarding different dimensions of economic development.

We can use the GVC as the organising principle for the analysis of India's globalisation because it permits us to focus on India's global business strategy - including mass customisation, core competence, branding, and other barriers to entry, financialisation, and inducing competition among suppliers - that are crucial for corporate profitability. In fact, the value chain approach is particularly relevant for developing countries (especially for its firms) that seek to capture dynamic gains from world trade that come with economic and social upgrading within and across value chains (Milberg \& Winkler 2013).

Engagement in GVCs would not bring economic prosperity automatically. It requires much more value added from India's potential productive factors and upgrading quality \& quantity of those factors with a strong distributional aspect of socioeconomic opportunities and outcomes. In this situation, Milberg \& Winkler (2013) rightly suggest that to understand the welfare implications of India's global production networks, we need a shift in emphasis from static efficiency gains (resulting from specialisation and exchange) to the questions of the sources and uses of profits for firm investment, employment demand, and innovation. However, this analysis - undoubtedly focused on the production side - indicates that a heightened disembodying of the market forces will not promote a socially sustainable growth path for India. Therefore, we have to think about the policy options to maximise the dynamic gains from GVC engagement. Besides this, Gereffi \& Fernandez-Stark (2016) think about various tasks, i.e. decision about different types of industrial or economic upgrading (process, product, functional, or inter-sector), densification, social upgrading (employment, wages, or labour standards) and types of GVC governance (power relations) that India wants to pursue. In this context, evaluation of risks due to external shocks for surviving in the value chains is also relevant to consider.

\subsection{Global Background}

Global value chains (GVCs) can simply be thought of as world wide web of economic value. From a business organization perspective, value chains describe the sequence of productive (value-added) activities that capital and labor (or firms and workers) perform to bring a good or service from its conception to end use and beyond (Porter 1985, Sturgeon 2001). "Value chain analysis" is intended 
as the science of identifying bottlenecks and opportunities between different stages of production and tasks. Value chains are said to be "global" when they include steps, processes, and actors from at least two countries (Gereffi et al. 2001, 2005); they can be regional if the scope of production takes place within the same geographic region. From an economic perspective, the phenomenon of global value chains (GVCs) identifies a production structure in which tasks and business functions are distributed among several companies, globally, or regionally (Grossman \& Rossi-Hansberg 2012). The key features of GVCs are therefore the international dimension of the production process and the "contractualisation" of buyer and seller relationships, often across international borders.

Producing high-quality goods and services in GVCs involves more than simply trading goods and services internationally. GVCs, in effect, integrate the know-how of lead firms and suppliers of key components along all the stages of production and in multiple companies and offshore locations. Typically coordinated by lead firms, GVCs involve international trade flows within their networks of foreign affiliates (foreign direct investment), contractual partners (non-equity modes of investment), and arm's-length external suppliers (UNCTAD 2013). When Toyota makes car parts in Thailand, it does not rely on local know-how. Instead, it imports Toyota technology, management, logistics, and any other bits of know-how not available in Thailand, because Thai-made parts have to fit seamlessly with parts made in Japan and elsewhere. GVCs, in effect, "unbundle" factories by offshoring firmspecific know-how along the stages of production, and those international flows of know-how are a key reason why GVCs offer unprecedented development opportunities to participating countries (Taglioni \& Winkler 2016).

Actually, well-functioning supply chains-which define the physical movement of goods all along the value chain, including domestic and international segments - are a key concern in GVCs. This is the case because good logistics, which defines the art of managing the supply chain and includes good connectivity, streamlined procedures for imports and exports, and low cost of logistics services, is an important determinant of countries' ability to join and strengthen participation in GVCs and a key factor in determining the costs of sourcing from and supplying to global markets. Getting to the border is one of the most pervasive constraints for exports of firms in low- and middle-income countries (LMICs), while the costs of logistics services can be disproportionately high for smaller and younger firms or for more remote locations. Improving logistics is also where LMICs have the most potential to reduce trade costs, according to recent surveys. Finally, well-functioning trade facilitation measures enable GVC trade by reducing the time, cost, and uncertainty involved in importing and exporting (Taglioni \& Winkler 2016).

But most production processes do not happen in a sequence of dependent activities. Instead, they 
take place in more complex networks of production, in which participating firms are specialists in one activity and external international sourcing arrangements imbue inter-firm trade with characteristics similar to intra-group trade: better control from the center, higher levels of bilateral information flow, tolerance of asset specificity, and harmonization and immediate integration of business processes that increase the potential for foreign activities to integrate seamlessly with activities performed at home. Large brand-carrying multinational enterprises (MNEs), such as IBM, Siemens, and Toyota, nowadays rely on a complex web of suppliers, vendors, and service providers of all kinds and in multiple locations. At the same time, a set of highly influential global buyers gained scale and influence in the 1990s, including retailers such as Walmart and Tesco and branded merchandisers such as Nike, Zara, and Uniqlo (Feenstra \& Hamilton 2006). Building on successful experiments in the 1970s and 1980s by a handful of pioneering retailers, such as J. C. Penney and Sears, global buyers nowadays place huge orders with suppliers around the world without establishing any factories or farms of their own (Gereffi 1999, Ponte \& Gibbon 2005). Unlike traditional MNEs, where equity ties link headquarters with foreign affiliates, global buyers link to their suppliers through non-equity external sourcing ties. Often, intermediaries (for example, trading companies such as Hong Kong SAR, China's Li \& Fung) are used to link buyers to producers in multiple countries (Taglioni \& Winkler 2016).

To highlight the complexity of the interactions among global producers, recent literature makes reference to the concept of global production "networks" rather than "chains" (Henderson et al. 2002). Accordingly, in the more realistic metaphor of networks, links can be seen as connecting nodes, some more central and some more peripheral. However, in this massive production network capital and labor are not the only factors of production. "Ideas" can be singled out as a third factor of production, although they could also be understood as high-skilled labor input. In a global context, the value-added activity performed in one country crosses international borders in goods or services tasks. Different tasks of the value chain contain a different amount of such factors of production. For example, specialized workers tend to be necessary in higher value-added tasks of the GVC. In the automotive, electronics, and electrical appliance industries, ideas are more strongly embedded in the early pre-production stages, such as research and development and design, or in post-production (logistics, marketing, and branding), thus requiring such specialized workers in those tasks. In other industries, notably the craft based ones (such as furniture making), innovation development is maximized when ideas (product design) and manufacturing operations are joint (Buciuni et al. 2013, Pisano \& Shih 2009), because innovation in those sectors often stems from a bottom-up approach (Breznitz \& Murphree 2011). 
Hence, by focusing on the sequences of tangible and intangible value-adding activities, from conception and production to end use, GVC analysis provides a holistic view of global industries both from the top down (for example, examining how lead firms "govern" their global-scale affiliate and supplier networks) and from the bottom up (for example, asking how these business decisions affect the trajectory of economic and social "upgrading" or "downgrading" in specific countries and regions).

\subsection{Indian Background}

India has emerged as one of the fastest growing economies in the world through different levels of liberalisation. Yet this growth has brought mixed economic and social outcomes. On one hand, recent studies of IMF and OECD show rising total factor productivity in Indian industry and exports have become more skill and capital intensive, suggesting that some Indian products are moving into tiers of value chains and that companies are generating demand for more skilled workers. On the other hand, different authors draw attention to problems of unbalanced growth between regions, the persistence of low quality informal work and adverse impact of trade liberalisation on more employment-intensive sectors and agriculture (Mazumdar \& Sarkar 2008, Pal et al. 2007). Given the rising prominence of India within the global economy and the need to create economic as well as social upgrading for its diverse forces of production, I should know more about India's increasing engagement in GVCs and its potential to contribute toward more inclusive economic and social development.

In this global bandwagon, India has not been left behind. India's participation into GVCs in the last two decades concerning the foreign content of its exports was more than double from less than $10 \%$ in 1995 to $24 \%$ in 2011. It has been argued that the increased participation GVCs is associated with the hollowing out of Indian manufacturing. Indian industrial sector is experiencing a rising output but falling value-added in total production (declining real value added growth and employment elasticity) with the trend becoming more pronounced since the mid-1990s. Besides this, dualism concerning 'formal', 'informal', and 'missing-middle' along with limiting regulations pose unique challenges to the growth of India's manufacturing (Banga 2014b). As Indian industries are facing an intense competition (domestic as well as external) linked with the global production sharing, the obvious increased use of imported inputs has caused a generalised decline in national value-added share for merchandise and total exports (Banga 2014a, Goldar et al. 2017, Veeramani \& Dhir 2017). Although India's output grows and exports rise, if the domestic value added does not rise, then there would be no noticeable production-linked gains like employment generation, technology upgrading, 
and skill development (Banga 2014b). It requires much more value added from India's potential productive factors and upgrading quality \& quantity of those factors with a proper distributional aspect of socioeconomic opportunities and outcomes (Banga 2014a).

In this new scenario, it is pertinent to ask how an economy's production processes, producers and employees are connecting to the world trade and capturing the dynamic gains out of it? In summary, the critical issue is: how to make GVCs work for development in our economy as a whole? This can be analysed through three stages of GVC integration, i.e. entering GVCs, expanding and strengthening GVC participation, and turning GVC participation into sustainable development (Taglioni \& Winkler 2016). Firstly, India's entry in manufacturing GVCs depends on its performance in improving connectivity to international markets (logistics), ensuring cost competitiveness, improving drivers of investment (ease of doing business), protecting assets, improving quality of infrastructure and services. Secondly, expansion and strength of India's GVC participation are dependent on the absorptive capacity (includes innovation capacity) of local actors to reap the benefits from knowledge \& technology spillovers and its compliance with the process and product standards. Thirdly, India's GVC participation can be sustained by creating a world-class workforce through promoting skill development, social upgrading, and equitable distribution of opportunities and outcomes. Indeed, Milberg \& Winkler (2013) rightly suggest a shift in emphasis from static efficiency gains (resulting from specialisation and exchange) to the questions of the sources and uses of profits for firm investment, employment demand, and innovation to understand the welfare implications of India's global production networks (dynamic gains). Some studies show that the impact of participation in GVCs has been mixed. Upgrading opportunities do exist within GVCs, but those studies show that these opportunities tend to be concentrated among certain regions, sectors, firms and workers rather than widespread. Furthermore, gains for MNCs do not automatically translate into gains for workers (Posthuma \& Nathan 2010).

Participation in certain types of value chains has been found to provide latecomer firms with a fast track to process and product upgrading (Schmitz 2004). This effect was confirmed among some domestic firms supplying to GVCs which improved their manufacturing process, enhanced product quality and sophistication, and raised productivity. Such firms have attained conformity with international technical and quality standards and increased their demand for skilled formal sector workers. These upgraded firms were mainly medium and large companies which had existing existing productive capacities and product development expertise prior to engagement with GVCs, or were companies which operate in higher technology and knowledge-intensive sectors such as information technology (IT). Positive spillovers were captured by smaller firms with adequate cash flow to invest 
in improved production practices and product quality, which also increased their requirements for skilled labour. As a result, workers with technical and managerial skills, many semi-skilled workers, and those having opportunities to learn on-the-job also benefited (Posthuma \& Nathan 2010).

Besides this, various exclusionary pressure also exist. Ponte (2008) draws attention to an adverse incorporation of smaller firms and lower-skilled workers which has led to the embedding of informal and precarious work within GVCs. Firms in less technologically sophisticated sectors with limited productive capacities faced upgrading barriers as well. There are also costs involved in upgrading, such as investments to attain quality. and product standards in the agri-food sector (Memedović \& Shepherd 2008). In some forms of value chain governance, lead firms may prevent upgrading of suppliers, leading to 'lock-in' at low value-added, low-wage tiers (Schmitz 2006, Gibbon \& Ponte 2005). In fact, the cost-cutting nature of much GVCs and fluctuations in order schedules put pressures upon suppliers to compete by keeping costs low, which includes low-wage, flexible labour practices. While first-tier suppliers may gain under such circumstances, they survive by shifting price pressures and risks to smaller firms down their value chain. These practices are largely seen in the labour-intensive sectors such as garments, agriculture, and leather products as well as mediumtechnology sectors such as auto components. These negative externalities restrict profitability and inhibit the scope of for smaller firms to invest in equipment, new practices, and quality certification. While many jobs have been created, different studies provide evidence of the use of informal work throughout the tiers of many sectoral value chains, even among firms in the formal sector. Employment opportunities for women workers have been created in high tech sectors for more highly educated women, but the majority of these jobs are in labour-intensive, low-wage sectors (Posthuma \& Nathan 2010).

\section{Literature Review}

\subsection{Broad Perspective}

Internationally fragmented production is not new. For decades, low- and middle-income countries (LMICs) have imported parts from countries with more advanced technology, although generally only for the assembly of locally sold goods. Because the goods produced were not part of a global network, flows of know-how were less intense. The new characteristic of GVCs from a development perspective is that factories in LMICs have become full-fledged participants in international production networks. They are no longer just importing parts for assembly for local sales. They are 
exporting goods, parts, components, and services customized to the needs of the intended buyers and used in some of the most sophisticated products on the planet (Taglioni \& Winkler 2016).

Given the need for customization and integration of production facilities internationally, large multi national corporations (MNCs) seek to improve local innovation, knowledge-based capital, and competencies. The Samsung Group—which employs 369,000 people in 510 offices worldwide—worries about shortages of technical and engineering skills in Africa and how those shortages affect its efforts to embed its African workforce in Samsung's global production networks. In 2011, to address such shortages, Samsung launched Samsung Electronics Engineering Academies in Kenya, Nigeria, and South Africa. Outstanding performers are sent to annual Learner ship Programs in Seoul as part of Samsung's program for young leaders. The initiative serves the company's broader goal to develop 10,000 electronics engineers across the continent by 2015 (ACET 2014). Other corporations are investing in building the skill base in LMICs, too (Dunbar et al. 2013). Lucent Technologies supports education and learning programs in 16 countries throughout Africa, Asia, Europe, and Latin America; Nike and the United Kingdom's Department for International Development run a program to support access to economic assets for adolescent girls; Microsoft provides support to incorporate information technology (IT) into the daily lives of young people in the Philippines, Poland, the Russian Federation, and South Africa; Cisco provides funds, expertise, and equipment to create national networks of IT training centers in India, Mexico, South Africa, and the West Bank and Gaza, in addition to the work of the Cisco Networking Academy, which has 10,000 academies in 165 countries; finally, Nokia enhances life skills and leadership skills of young people in several countries, including Brazil, China, and Mexico (Taglioni \& Winkler 2016).

The new GVC-enabled flow of know-how from high-income countries to LMICs is a key factor in determining the role of GVCs in industrial development. LMICs can now industrialize by joining GVCs without the need to build their own value chain from scratch, as Japan and the Republic of Korea had to do in the twentieth century (Baldwin et al. 2012). That enables LMICs to focus on specific tasks in the value chain rather than producing the entire product, thereby lowering the threshold and costs for industrial development. LMICs can benefit from foreign-originated intellectual property; trademarks; operational, managerial, and business practices; marketing expertise; and organizational models. Countries have to understand the opportunities that GVCs offer and adopt the appropriate policies to mitigate the risks associated with them have the opportunity - through GVCs - to boost employment and productivity in all their agriculture, manufacturing, and services production. Job creation and labor productivity growth are sometimes viewed as competing goals, as higher labor productivity enables firms to produce a larger amount of value added without necessar- 
ily increasing the number of workers at the same rate (static productivity effects). Research shows that GVC integration leads to higher net jobs but lower job intensity (Calì et al. 2016, 2015) and has strong potential for productivity gains via several transmission channels (dynamic productivity effects), as discussed later, which go in hand with increased labor demand caused by more vertical specialization and higher output in GVCs.

\subsection{Firm Perspective}

The international location of new production facilities is ultimately in the hands of GVC lead firms. Conceptually, the new possibilities created by globalization and the information and communications technology revolution create two distinct sets of necessities for firms, which countries must address: (1) connecting factories and (2) protecting assets. Because cross-border factories must work as a unit, lead firms in GVCs care about efficiently connecting local factories with the relevant international production network and protecting proprietary assets. The predictability, reliability, and time sensitivity of trade flows are important factors behind firms' decision about a location, according to major trade and competitiveness indexes and case studies (WEF 2013). In many cases, countries cannot participate in certain parts of GVCs because of requirements for timely production and delivery. In effect, time is money in GVCs. A day of delay in exporting has a tariff equivalent of 1 percent or more for time-sensitive products (Hummels et al. 2007). Slow, unpredictable land transport keeps most of Sub-Saharan Africa out of the electronics value chain (Christ \& Ferrantino 2011). Lead firms and intermediate producers in GVCs need reliable, predictable, and timely access to inputs and final products to satisfy demand on time. Hence, good infrastructure and efficient borders are critical, as they relate to the predictability, reliability, and time sensitivity of trade flows.

Strong, well-enforced property rights are the other element essential to attracting and keeping foreign investors (Feenstra et al. 2013). Firms export valuable, firmspecific technology and know-how, only part of which can be protected through patents, trademarks, and other forms of intellectual property regulations (IPRs). The know-how embodied in business and organizational models, operational and managerial practices, production processes, and export processes cannot be patented or trademarked; and even when intellectual property can be patented or trademarked, IPR treaties and domestic regulations aimed at promoting fair competition only imperfectly protect such know-how. Because GVCs necessarily involve contracting relationships between agents located in countries with heterogeneous legal systems and contracting institutions, "contracts are often neither explicit nor implicit; they simply remain incomplete" (Rodrik 2000). The way in which different national systems deal with contractual frictions and incomplete contracts and the way host countries enforce 
contracts between private parties are additional elements driving firms' choice of location, and those elements also factor into firms' boundaries in global sourcing (Antràs \& Chor 2013, Antràs \& Yeaple 2015). The connectivity of factories and the nature of contracting across countries are therefore key determinants—along with capital intensity—of a firm's decision to make or buy and whether to do so domestically or internationally.

Control of the subsidiary takes place in a variety of ways. The most strategic assets are tied to the lead firm through forms of direct capital control over the supplier (such as majority equity stakes). Assets of lower importance (such as older technologies) are instead just handed over through licensing agreements or other non-equity investments. Technical cooperation and arm's-length trade signal looser forms of collaboration. With the dramatic growth of outsourcing practices, competition between companies has shifted from horizontal (with firms competing in the same sector for the same customer base) to vertical (with firms in the same value chain competing to perform specific and specialized tasks). Lead firms compete with first-tier and lower-tier suppliers (Milberg 2004, Cattaneo et al. 2013, Cattaneo \& Miroudot 2013).

\subsection{Policy Perspective}

In the same way that import substitution industrialization gave way to export-oriented industrialization, the latter is now being replaced by efforts to identify an entry point into vertically specialized industries and upgrade within GVCs. Attracting offshore factories and ensuring domestic firm participation in international GVCs has become a major priority for many policy makers in LMICs. From a policy perspective, however, the critical issue is how GVCs integrate into the economy as a whole. Attracting and keeping offshore factories is not enough. Opening borders and attracting investment are important and help jump-start entry in GVCs. But to retain GVCs, maximize their benefit to the domestic economy, and ensure their sustainability, countries must integrate the domestic productive sector. The policy challenge extends, therefore, to creating and strengthening links with domestic firms and ensuring that the host country benefits from technology transfers, knowledge spillovers, and increased value addition in the country. If GVCs remain de-linked from the local context, lead firms drive many decisions, and governments may have limited influence and ability to leverage such decisions for domestic economic development. It is equally important to ensure that GVC participation benefits domestic society through more and better-paid jobs, better living conditions, and social cohesion. The right strategies can help LMICs increase and strengthen their participation in GVCs and foster development. Therefore, one of my aims (in this proposal) will be to discuss those right strategies with their enforcement and implications (quantitative as well 
as qualitative).

Nevertheless, a point to remember is that to create an effective and sustainable strategy of GVC participation, governments must focus on identifying key binding constraints and designing the necessary policy and regulatory interventions-as well as infrastructure and capacity building-with a "whole of value chain approach". Such an approach is needed to achieve development objectives through GVC participation and address specific challenges in entering GVCs, expanding and strengthening participation, and ensuring sustainability and inclusive growth. Trade and investment policies need to be connected with a wide-ranging domestic reform agenda aimed at helping countries enhance firms' productivity by building internal capacities and providing access to capital and connectivity, and ensuring a responsive and effective governance structure for identifying opportunities and addressing challenges from GVC participation.

According to Taglioni \& Winkler (2016), GVCs require targeted policies and analysis across a wide range of areas, which may not always be easy for a country's policy makers to formulate and connect to each other and to GVCs. Governments may not necessarily be aware of the effects of domestic policies on integration and upgrading in GVCs. The odds of success in GVCs are affected by policy and its implementation in areas as different as trade (tariff and nontariff barriers), domestic services regulations, investment regulations and incentives, compliance with process and product standards, innovation, industry, entrepreneurship, labor markets, education, and infrastructure and connectivity. Countries may not appreciate fully the importance of the synergies between the core areas of trade and investment regulation and well-tailored complementary measures. Countries also may not be able to identify the appropriate investment in education and vocational training, infrastructure, and connectivity; the best setting for labor market policies; which international standards to adopt; how to design and develop adequate supplier programs; effective cluster development programs and competitive spaces (special economic zones, growth poles, growth corridors, and so forth); or services regulations conducive to business efficiency. Finally, countries may not be able to identify and implement sustainable and effective financing and incentive schemes.

Even when governments are aware of these issues, putting in place regulations that do not unnecessarily restrict effectiveness in GVC participation may be difficult. In most countries, many agencies have a role in setting and enforcing regulation that may affect value chains and the efficiency of their supply chain. Those agencies also often legislate and implement regulation in an uncoordinated manner because regulators set policies with domestic regulatory objectives in mind. As a consequence, international coordination is not necessarily able to foster GVCs' production and trade along the corresponding supply chain. International coordination conflicts with domestic regulatory 
objectives may explain why existing trade agreements, investment agreements, and similar forms of international cooperation are rarely designed to foster GVC participation (Hoekman 2014).

Given this background, OECD, WTO, World Bank, and different international as well as regional institutions are constantly suggesting that the policy maker's priority should be to identify and lift binding constraints, unlock productivity growth, and improve the overall competitiveness of the country. Many governments are willing to invest significant time and effort to adopt policy that influences the cost of production and trade within a GVC. The appropriate analysis and policy strategies can help trigger a virtuous cycle of "reform—GVC entry and upgrading—-development", whereby the private sector is encouraged to keep investing retained earnings in the continued improvement of existing activities, new activities, and comparative advantage tasks in countries' agriculture, manufacturing, and services sectors, thereby generating a process of inclusive growth for the host country.

\subsection{Innovation Perspective}

Pietrobelli \& Rabellotti (2011) shows that Innovation, as a chain of processes, interact with GVC in multiple ways, and influence whether and how developing country firms learn and innovate through entering and interacting in these value chains. In general, LDC firms learn and innovate based on their participation in the GVC because they have to satisfy the product quality, delivery time, process efficiency, environmental, labor and social standards requirements of these chains. The learning mechanisms within GVC vary according to the form of governance that is adopted: they can be the result of pressure to match international standards or may be facilitated by direct involvement of the value chain leaders if the competence of suppliers is low and the risk noncompliance is high. When the actors in the value chain have complementary competences, learning is mutual and based on intense face-to-face interactions. In fact, it is from the 1980s on, with the debates surrounding the interpretation of the innovation process, that the perspective of innovation as a systemic and interactive process appears in the academic literature and in OECD policy documents, highlighting the importance of firms' both formal and informal networks, and giving rise to the concept of the innovation system (Szapiro 2016).

According to Lundvall et al. (2015), the notion of Innovation Systems, initiated by Economists bringing in the social dimension, is predominantly national level with advice on the design of national institutions and state policies for interactive learning between equal partners. Whereas the GVC approach, initiated by Sociologists bringing in economic perspectives, is developed to overcome limitations of nation state perspectives, where "governance" as the power dimension between 
the lead firm and the other firms in the value chain. Innovation System and Global value chain approach both see the promotion of development in less developed economies as the objective. Although these two approaches have common objective, but they are different mechanisms. Innovation system approach is about building absorptive capacity in less developed economies. Global value chain is about upgrading firms through linking up with foreign lead firms. Moreover, in terms of policy implications, the GVCs framework suggests that reducing trade barriers and policies aimed at attracting subsidiaries of multinational firms become a better alternative to industrial policies focused on substituting imports and increasing local content (Gereffi \& Sturgeon 2013). The literature on innovation systems, on the other hand, provides important elements for the understanding of the capability building process within firms, industries and sectors in developing countries (Szapiro 2016).

Actually, each approach has some obvious limitations. We know (from policy perspective) that to design intelligent institutions and policies at the national level requires an understanding of of the openness of the innovation system, which limits the scope of national system of innovation. Managing the openness including the dependence of foreign multinational firms is a major challenge for national governments. On the other hand, to understand how and to what degree a specific firm's or cluster's integration in a global value chain contributes to economic development requires an understanding of the national innovation system as context. However, there is a couple of earlier attempts to overcome these limitations. Pietrobelli \& Rabellotti (2011) started from Global Value Chain analysis and argue for including local, regional and national institutions' roles in upgrading opportunities. Ernst \& Kim (2002) started from Innovation System perspective and point to the need to take into account the role of global networks in relation innovation strategies. Malerba \& Nelson (2010) emphasised on catching-up and sectoral systems also combined the two perspectives. Indeed, the relationship between the GVC and IS is intrinsically dynamic, with frequent two-way directions of causality and continuous feedback. Governance patterns in GVC are dynamic and subject to continuous adjustments and changes. The characteristics of the innovation system affect this evolution. Therefore I should explore the co-evolving link between suppliers and the lead firms, and with them, of the related IS.

\section{References}

Antràs, P. (2016), Global Production: Firms, Contracts, and Trade Structure, Princeton University Press. 
Banga, R. (2014a), 'Linking into global value chains is not sufficient: do you export domestic value added contents?', Journal of Economic Integration pp. 267-297.

Banga, R. (2014b), 'Trade facilitation and 'hollowing-out' of indian manufacturing', Economic and Political Weekly 49(40), 57-63.

Breznitz, D. \& Murphree, M. (2011), Run of the red queen: Government, innovation, globalization, and economic growth in China, Yale University Press.

Buciuni, G., Coro', G. \& Micelli, S. (2013), 'Rethinking the role of manufacturing in global value chains. An international comparative study in the furniture industry', Industrial and Corporate Change pp. 1-30.

Feenstra, R. C. (1998), 'Integration of trade and disintegration of production in the global economy', The journal of economic perspectives 12(4), 31-50.

Feenstra, R. C. \& Hamilton, G. G. (2006), Emergent economies, divergent paths: Economic organization and international trade in South Korea and Taiwan, Vol. 29, Cambridge University Press.

Gereffi, G. (1999), 'International trade and industrial upgrading in the apparel commodity chain', Journal of international economics 48(1), 37-70.

Gereffi, G. \& Fernandez-Stark, K. (2016), Global value chain analysis: a primer, Duke CGGC (Center on Globalization, Governance \& Competitiveness).

Gereffi, G., Humphrey, J., Kaplinsky, R. \& Sturgeon*, T. J. (2001), 'Introduction: Globalisation, Value Chains and Development', IDS Bulletin 32(3), 1-8.

Gereffi, G., Humphrey, J. \& Sturgeon, T. (2005), 'The governance of global value chains', Review of International Political Economy 12(1), 78-104.

Gibbon, P. \& Ponte, S. (2005), Trading down: Africa, value chains, and the global economy, Temple University Press.

Goldar, B., Das, D. K., Sengupta, S. \& Das, P. C. (2017), 'Domestic value addition and foreign content: An analysis of india's exports from 1995 to 2011', ICRIER Working Paper 332 .

Grossman, G. M. \& Rossi-Hansberg, E. (2012), ‘Task trade between similar countries', Econometrica $80(2), 593-629$. 
Henderson, J., Dicken, P., Hess, M., Coe, N. \& Yeung, H. W.-C. (2002), 'Global production networks and the analysis of economic development', Review of International Political Economy 9(3), 436-464.

Mazumdar, D. \& Sarkar, S. (2008), Globalization, labor markets and inequality in India, Vol. 79, Idrc.

Memedović, O. \& Shepherd, A. (2008), Agri-food Value Chains and Poverty Reduction: Overview of Main Issues, Trands and Experiences, United Nations Industrial Development Organization.

Milberg, W. \& Winkler, D. (2013), Outsourcing economics: global value chains in capitalist development, Cambridge University Press.

Pal, P., Ghosh, J. et al. (2007), 'Inequality in india: A survey of recent trends', Economic and Social Affairs Working Paper 45.

Pisano, G. P. \& Shih, W. C. (2009), 'Restoring american competitiveness'.

Ponte, S. (2008), 'Developing a vertical dimension to chronic poverty research: Some lessons from global value chain analysis', Chronic Poverty Research Centre Working paper .

Ponte, S. \& Gibbon, P. (2005), 'Quality standards, conventions and the governance of global value chains', Economy and Society 34(1), 1-31.

Porter, M. E. (1985), Competitive Advantage: Creating and sustaining superior performance, The Free Press.

Posthuma, A. \& Nathan, D. (2010), Labour in Global Production Networks in India, Oxford University Press.

Schmitz, H. (2004), Local upgrading in global value chains: recent findings, in 'International Convention Centre. Durban, South Africa', Vol. 21, pp. 1-8.

Schmitz, H. (2006), 'Learning and earning in global garment and footwear chains', The European Journal of development research 18(4), 546-571.

Sturgeon, T. J. (2001), How Do We Define Value Chains and Production Networks?, Technical Report 3, IDS Bulletin.

Taglioni, D. \& Winkler, D. (2016), Making Global Value Chains Work for Development, Vol. Trade and Development series, Washington, DC: World Bank.

UNCTAD (2013), 'Global value chains and development', World Investment Report 2013 . 
Veeramani, C. \& Dhir, G. (2017), 'Domestic value added content of india's exports: Estimates for 112 sectors, 1999-2000 to 2012-13', IGIDR Working Paper .

ACET (2014), African transformation report: Growth with depth, Technical report, African Center for Economic Transformation, Accra, Ghana: ACET.

Antràs, P. \& Chor, D. (2013), 'Organizing the Global Value Chain', Econometrica 81(6), 21272204.

Antràs, P. \& Yeaple, S. R. (2015), 'Multinational Firms and the Structure of International Trade', Handbook of International Economics 4, 55-130.

Baldwin, R., Venables, A. J. \& Bridgman, B. (2012), 'Global supply chains: Why they emerged, why they matter, and where they are going', Journal of International Economics 90(1), 245-254.

Calì, M., Francois, J., Hollweg, C. H., Manchin, M., Oberdabernig, D. A., Rojas-Romagosa, H., Rubinova, S. \& Tomberger, P. (2016), 'The labor content of exports database', World Bank Policy Research Working Paper 7615.

Calì, M., Hollweg, C. et al. (2015), The labor content of exports in south africa and botswana, Technical report, The World Bank.

Cattaneo, O., Gereffi, G., Miroudot, S. \& Taglioni, D. (2013), 'Joining, upgrading and being competitive in global value chains: a strategic framework', World Bank Policy Research Working Paper 6406 pp. 1-50.

Cattaneo, O. \& Miroudot, S. (2013), 'From global value chains to global development chains: An analysis of recent changes in trade patterns and development paradigms', 21st Century Trade Policy: Back to the Past.

Christ, N. \& Ferrantino, M. J. (2011), 'Land Transport for Export: The Effects of Cost, Time, and Uncertainty in Sub-Saharan Africa', World Development 39(10), 1749-1759.

Dunbar, M. et al. (2013), 'Engaging the private sector in skills development', Health \& Education Advice and Resource Team. Oxford Policy Management, Oxford, England .

Ernst, D. \& Kim, L. (2002), 'Global production networks, knowledge diffusion, and local capability formation', Research policy 31(8), 1417-1429.

Feenstra, R. C., Hong, C., Ma, H. \& Spencer, B. J. (2013), 'Contractual versus non-contractual trade: The role of institutions in China', Journal of Economic Behavior and Organization 94, 281-294. 
Gereffi, G. \& Sturgeon, T. (2013), 'Global value chain-oriented industrial policy: the role of emerging economies', Global value chains in a changing world p. 329.

Hoekman, B. (2014), 'Supply chains, mega-regionals and multilateralism: a road map for the wto', Robert Schuman Centre for Advanced Studies Research Paper No. RSCAS 27.

Hummels, D., Minor, P., Reisman, M. \& Endean, E. (2007), ‘Calculating tariff equivalents for time in trade', USAID Report, March .

Lundvall, B., Jurowetzki, R. \& Lema, R. (2015), 'Combining the global value chain and the innovation system perspectives', Aalb. Univ. Dep. Bus. Manag .

Malerba, F. \& Nelson, R. (2010), Catching up in different sectoral systems: evidence from six industries, in 'Globelics Conference, Kuala Lumpur, Malaysia', p. 2010.

Milberg, W. (2004), 'The changing structure of trade linked to global production systems: What are the policy implications?', International Labour Review 143 (1-2),(1), 45-90.

Pietrobelli, C. \& Rabellotti, R. (2011), 'Global value chains meet innovation systems: are there learning opportunities for developing countries?', World Development 39(7), 1261-1269.

Rodrik, D. (2000), 'How Far Will International Economic Integration Go?', Journal of Economic Perspectives 14(1), 177-186.

Szapiro, M. (2016), Global Value Chains and National Systems of Innovation: policy implications for developing countries, $\mathrm{PhD}$ thesis, Universidade Federal do Rio de Janeiro.

WEF (2013), Enabling trade: Valuing growth opportunities, in 'World Economic Forum'. 